\title{
Analisis Faktor Pendukung Penjualan pada DOC Ayam Broiler Menggunakan Algoritma MO0RA pada PT. Karya Semangat Mandiri Pematangsiantar
}

\author{
Agnes Gracella Fepdiani Simanjuntak ${ }^{1}$, Agus Perdana Windarto² ${ }^{2}$ Eka Irawan ${ }^{3}$ \\ STIKOM Tunas Bangsa, Pematangsiantar, Indonesia \\ Jln Jendral Sudirman Blok A No. 1/2/3 Pematangsiantar \\ agnesgracella80@gmail.com
}

\begin{abstract}
Day Old Chicken (DOC) is one day old chicken, usually weighs and weighs an average of 35-40 grams. Researchers took a case study at PT. Karya Semangat Mandiri which is a child of PT. Charoen Pokphand where the company produces animal feed, Day Old Chicks and Indonesia's largest processed food company in Balaraja is one of the leading companies in the field of agribusiness in Indonesian. PT. Karya Semangat Mandiri is a subsidiary where in its implementation it still has problems, especially in the selection of Broiler Chicken DOC quality that will be distributed to several partners that have been incorporated. In this study, the authors analyzed the strategy of increasing sales in the selection of Broiler Chicken DOC Quality using the MOORA Algorithm. The author obtained data directly from PT. Karya Semangat Mandiri. The attributes used are eight, namely the title (C1) , abstract (C2), introduction (C3) , objectives (C4), methods (C5), results and discussion (C6), conclusions (C7) and bibliography (C8). With this analysis, it is expected recomended to PT. Karya Semangat Mandiri in increasing sales so that it can add partners who want to join in it based on the algorithm used.
\end{abstract}

Keywords: Decision Support System, Quality, MOORA, Day Old Chicken(DOC), Broiler Chicken

Abstrak- Day Old Chicken (DOC) merupakan ayam berumur satu hari, biasa berat dan bobotnya rata-rata 35-40 gram. Peneliti mengambil studi kasus pada PT. Karya Semangat Mandiri yang merupakan anak dari PT. Charoen Pokphand dimana perusahaan ini menghasilkan pakan ternak, Day Old Chicks dan makanan olahan terbesar di Indonesia perusahaan yang ada di Balaraja menjadi salah satu perusahaan terkemuka di bidang agrobisnis di Indonesia. PT. Karya Semangat Mandiri merupakan anak cabang dimana dalam pelaksanaan nya masih memiliki kendala, khususnya dalam pemilihan kualitas DOC Ayam Broiler yang akan disebar kebeberapa mitra yang sudah tergabung. Pada penelitian ini, penulis melakukan analisis strategi peningkatan penjualan dalam pemilihan Kualitas DOC Ayam Broiler dengan menggunakan Algoritma MOORA. Penulis memperoleh langsung data dari PT. Karya Semangat Mandiri. Atribut yang digunakan sebanyak delapan, yaitu judul (C1), abstrak (C2), pendahuluan (C3), tujuan (C4), metode (C5), hasil dan pembahasan (C6), kesimpulan (C7), dan daftar pustaka (C8). Dengan analisis ini diharapkan dapat menjadi rekomendasi kepada pihak PT. Karya Semangat Mandiri dalam melakukan peningkatan penjualan sehingga dapat menambah mitra yang ingin bergabung didalamnya berdasarkan Algoritma yang digunakan.

Kata kunci : Sistem Pendukung Keputusan, Kualitas, MOORA, Day Old Chicken (DOC), Ayam Broiler 


\section{PENDAHULUAN}

Peternakan ayam broiler mempunyai prospek yang sangat baik untuk dikembangkan, baik dalam skala peternakan besar maupun skala peternakan kecil (peternakan rakyat). Ayam broiler merupakan ternak ayam yang paling cepat pertumbuhannya, hal ini karena ayam broiler merupakan hasil budidaya yang menggunakan teknologi maju, sehingga memiliki sifat-sifat ekonomi yang menguntungkan[1]. Broiler adalah istilah untuk menyebut ayam hasil budidaya teknologi yang memiliki karakteristik ekonomis, dengan ciri khas pertumbuhan cepat sebagai penghasil daging, konversi pakan irit, siap dipotong pada usia relatif muda, serta menghasilkan daging berkualitas serat lunak. Peternakan ayam broiler mempunyai banyak kelebihan, salah satunya adalah siklus produksi yang sangat pendek yaitu sekitar 30-40 hari. Berdasarkan permasalahan diatas, maka penulis mengangkat judul "Analisis Faktor Pendukung Penjualan pada DOC Ayam Broiler menggunakan Algoritma Multi Objective Optimization on the Basis of Ratio Analysis (MOORA) pada PT. Karya Semangat Mandiri Pematangsiantar. Metode Multi-Objective Optimization on the Basis of Ratio Analysis (MOORA) merupakan salah satu metode Sistem Pendukung Keputusan. Ada banyak penelitian-penelitian menggunakan metode Sistem Pendukung Keputusan [2][12]. Metode MOORA merupakan metode Sistem Pendukung Keputusan yang menentukan nilai bobot untuk setiap atribut, kemudian dilanjutkan dengan proses perankingan yang akan menyeleksi alternatif terbaik dari sejumlah alternatif yang ada. Metode ini memiliki tingkat fleksibilitas yang tinggi dan kemudahan dalam memisahkan bagian subjektif dari suatu proses evaluasi ke dalam kriteria bobot keputusan dengan beberapa atribut pengambilan keputusan. Selain itu, metode Metode Multi-Objective Optimization on the Basis of Ratio Analysis (MOORA) juga memiliki tingkat selektifitas yang baik karena dapat menentukan tujuan dari kriteria yang bertentangan yang mana kriteria dapat bernilai menguntungkan (benefit) atau yang tidak menguntungkan (cost)[13].

\section{METODOLOGI PENELITIAN}

Metode yang digunakan dalam penelitian ini adalah salah satu dari bagian Sistem Pendukung Keputusan (SPK) yaitu metode MOORA merupakan multiobjektif sistem yang mengoptimalkan dua atau lebih atribut yang saling bertentangan secara bersamaan. Metode ini diterapkan untuk memecahkan maslaah dengan perhitungan matematika yang kompleks[14]. MO0RA juga dapat dipergunakan untuk memecahkan berbagai masalah pengambilan keputusan yang rumit pada lingkungan pabrik. Metode MOORA diterapkan juga untuk memecahkan banyak permasalahan ekonomi, manajerial, dan konstruksi pada semua perusahaan maupun proyek. Algoritma penelitian pada proposal skripsi ini dapat dideskripsikan sesuai diagram alir berikut ini : 


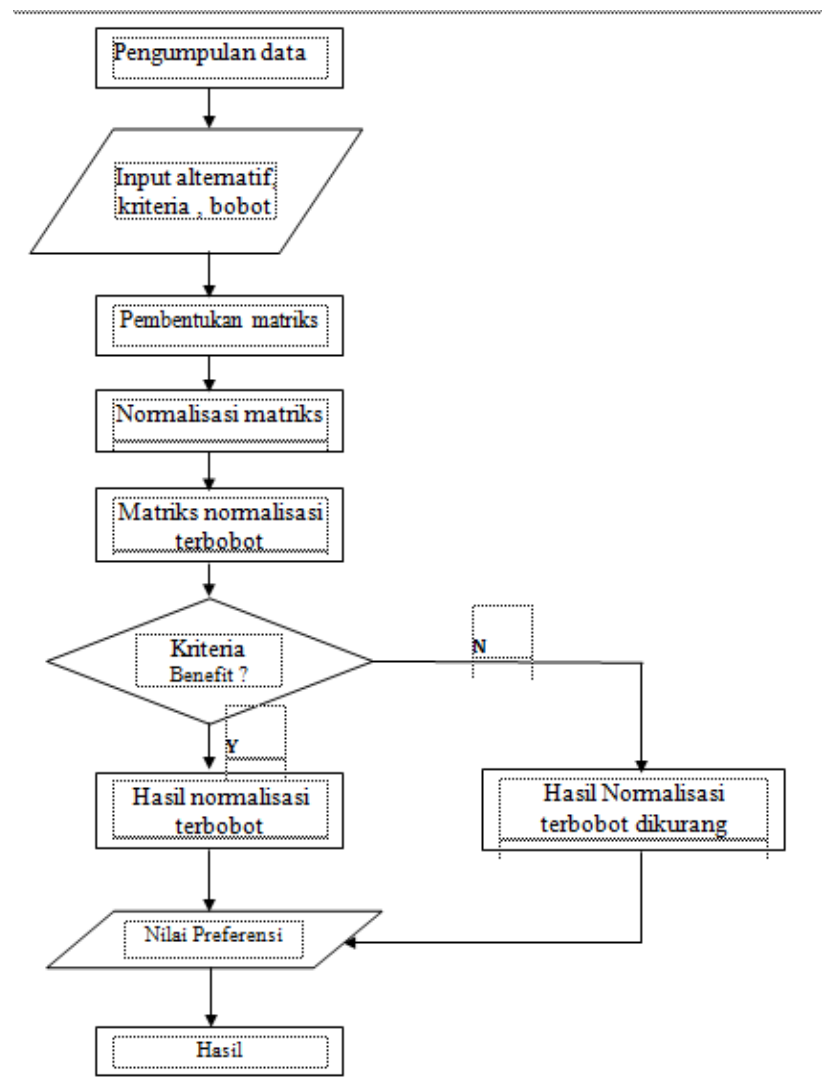

Gambar 1. Diagram Alir

Dalam meningkatkan penjualan DOC broiler diperlukan metode yamg tepat untuk melakukan analisa dan perhitungan dari setiap kriteria-kriteria yang telah ditentukan[15]. Pada penelitian ini, penulis menggunakan metode Multi Objective Optimization on the Basis of Ratio Analysis (MOORA) dapat mengidentifikasi atribut evaluasi yang bersangkutan dan menginputkan nilai kriteria pada suatu alternatif dimana nilai tersebut nantinya akan diproses dan hasilnya akan menjadi sebuah keputusan. Berikut ini merupakan analisis permasalahan pada penulisan proposal skripsi. Dapat dilihat pada gambar 3.2. berikut :

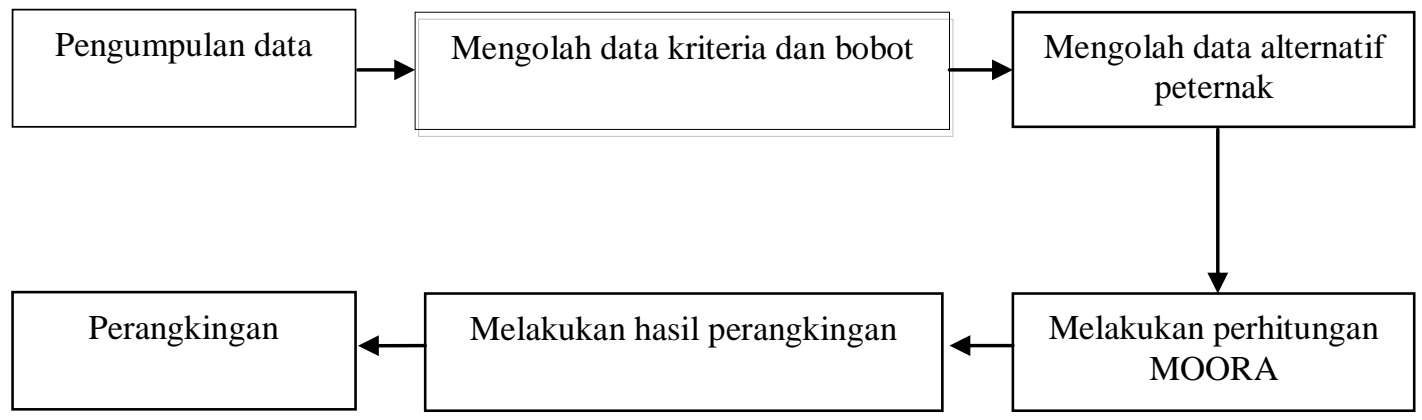

Gambar 2. Diagram Alir Blog Penelitian 


\section{HASIL DAN PEMBAHASAN}

Data diperoleh dengan melakukan wawancara secara langsung kepada peternak dan membagikan selebaran kuesioner yang diisi masing-masing peternak yang telah bermitra pada PT. Karya Semangat Mandiri Pematangsiantar yang ada di wilayah Siantar - Simalungun dan sekitarnya. Dari hasil wawancara dan kuesioner diperoleh kriteria dan alternatif sebagai data yang akan digunakan untuk melakukan perhitungan. Adapun kriteria yang digunakan dalam penelitian ini sebanyak 10 (sepuluh) peternak. Dapat dilihat pada tabel 4.1 ialah sebagai berikut:

Tabel 1. Kriteria

\begin{tabular}{|c|c|}
\hline \multicolumn{2}{|c|}{ KRITERIA } \\
\hline Rianto Sinaga & C1 \\
\hline Loren Saragih & C2 \\
\hline Gabe & C3 \\
\hline Arjo & C4 \\
\hline Panatap & C5 \\
\hline Sri & C6 \\
\hline Anton & C7 \\
\hline Sari & C8 \\
\hline Santoso & C9 \\
\hline Budi & C10 \\
\hline
\end{tabular}

Adapun alternatif yang digunakan dalam penelitian ini sebanyak 8 (Delapan). Dimana alternatif dari keseluruhan dapat dilihat pada tabel 4.2 sebagai berikut :

Tabel 2. Alternatif

\begin{tabular}{|c|c|}
\hline \multicolumn{2}{|c|}{ ALTERNATIF } \\
\hline Harga & A1 \\
\hline Pakan & A2 \\
\hline DOC Ayam & A3 \\
\hline Obat / Vaksin & A4 \\
\hline Pemanas & A5 \\
\hline Kandang & A6 \\
\hline Vitamin & A7 \\
\hline Anak Kandang & A8 \\
\hline
\end{tabular}

Pembobotan dari setiap kriteria adalah sebagai berikut:

Tabel 3. Pembobotan Harga

\begin{tabular}{|c|c|c|}
\hline Pekerjaan & Bobot & Nilai \\
\hline >Rp. 10.000 & Sangat Baik & 5 \\
\hline Rp.9.9000 - Rp.8.000 & Cukup Baik & 4 \\
\hline Rp.7.900 - Rp.6.000 & Baik & 3 \\
\hline Rp.5.900 - Rp.4.000 & Cukup & 2 \\
\hline <Rp.3.900 & Buruk & 1 \\
\hline \multicolumn{2}{|c|}{ Cost 10\% } \\
\hline
\end{tabular}

Tabel 4. Pembobotan Pakan

\begin{tabular}{|c|c|}
\hline Bobot & Nilai \\
\hline Sangat Baik & 5 \\
\hline Cukup Baik & 4 \\
\hline Baik & 3 \\
\hline \multicolumn{2}{|c|}{ Cost $10 \%$} \\
\hline
\end{tabular}


Tabel 5. Pembobotan DOC Ayam

\begin{tabular}{|c|c|c|}
\hline Pekerjaan & Bobot & Nilai \\
\hline$>40 \mathrm{gr}$ & Sangat Baik & 5 \\
\hline $39 \mathrm{gr}-36 \mathrm{gr}$ & Cukup Baik & 4 \\
\hline $35 \mathrm{gr}-30 \mathrm{gr}$ & Baik & 3 \\
\hline $29 \mathrm{gr}-25 \mathrm{gr}$ & Cukup & 2 \\
\hline$<24 \mathrm{gr}$ & Buruk & 1 \\
\hline \multicolumn{3}{|c|}{ Cost $10 \%$} \\
\hline
\end{tabular}

Tabel 6. Pembobotan Obat/Vaksin

\begin{tabular}{|c|c|}
\hline Bobot & Nilai \\
\hline Sangat Baik & 5 \\
\hline Cukup Baik & 4 \\
\hline Baik & 3 \\
\hline \multicolumn{2}{|c|}{ Cost $10 \%$} \\
\hline
\end{tabular}

Tabel 7. Pembobotan Alat Pemanas

\begin{tabular}{|c|c|}
\hline Bobot & Nilai \\
\hline Sangat Baik & 5 \\
\hline Cukup Baik & 4 \\
\hline Baik & 3 \\
\hline \multicolumn{2}{|c|}{ Cost $10 \%$} \\
\hline
\end{tabular}

Tabel 8. Pembobotan Kandang

\begin{tabular}{|c|c|}
\hline Bobot & Nilai \\
\hline Sangat Baik & 5 \\
\hline Cukup Baik & 4 \\
\hline Baik & 3 \\
\hline \multicolumn{2}{|c|}{ Cost $10 \%$} \\
\hline
\end{tabular}

Tabel 9. Pembobotan Vitamin

\begin{tabular}{|c|c|}
\hline Bobot & Nilai \\
\hline Sangat Baik & 5 \\
\hline Cukup Baik & 4 \\
\hline Baik & 3 \\
\hline \multicolumn{2}{|c|}{ Cost $10 \%$} \\
\hline
\end{tabular}

Tabel 10. Pembobotan Anak Kandang

\begin{tabular}{|c|c|}
\hline Bobot & Nilai \\
\hline Aktif & 5 \\
\hline Tidak Aktif & 2 \\
\hline \multicolumn{2}{|c|}{ Cost $10 \%$} \\
\hline
\end{tabular}

Metode MOORA memiliki tingkat selektifitas yang baik, karena dapat menentukan tujuan dari kriteria yang bertentangan[16]. Dimana menentukan bobot kriteria ada 2 (dua) nilai bobot dapat bernilai menguntungan (benefit) seperti berhubungan dengan angka numerik dan yang tidak menguntungkan (cost). Dalam penelitian ini digunakan nilai bobot kriteria cost karena bobot kriteria tidak mengandung angka didalamnya. Dengan bobot dari setiap kriteria adalah sebagai berikut:

Tabel 11. Bobot Kriteria

\begin{tabular}{|c|c|c|c|c|c|c|c|c|c|c|}
\hline C1 & C2 & C3 & C4 & C5 & C6 & C7 & C8 & C9 & C10 & Total \\
\cline { 1 - 9 } $10 \%$ & $10 \%$ & $10 \%$ & $10 \%$ & $10 \%$ & $10 \%$ & $10 \%$ & $10 \%$ & $10 \%$ & $10 \%$ & $100 \%$ \\
\cline { 1 - 8 }+ & + & + & + & + & + & + & + & + & + & \\
\hline
\end{tabular}

Berdasarkan data dari kriteria yang diperoleh dari masing-masing peternak maka dihasilkan rating kecocokan dari setiap alternatif, seperti pada tabel berikut :

Tabel 12. Rating Kecocokan

\begin{tabular}{|c|c|c|c|c|c|c|c|c|c|c|}
\hline Alternatif & C1 & C2 & C3 & C4 & C5 & C6 & C7 & C8 & C9 & C10 \\
\hline A1 & 5 & 5 & 5 & 2 & 3 & 1 & 3 & 4 & 4 & 2 \\
\hline A2 & 4 & 4 & 3 & 3 & 5 & 5 & 4 & 4 & 4 & 3 \\
\hline A3 & 5 & 1 & 2 & 3 & 5 & 2 & 4 & 5 & 1 & 1 \\
\hline A4 & 3 & 3 & 4 & 4 & 5 & 4 & 5 & 3 & 5 & 5 \\
\hline A5 & 3 & 3 & 4 & 4 & 5 & 3 & 4 & 4 & 3 & 4 \\
\hline A6 & 4 & 3 & 4 & 5 & 3 & 5 & 5 & 4 & 4 & 3 \\
\hline A7 & 4 & 4 & 5 & 4 & 4 & 3 & 5 & 5 & 5 & 4 \\
\hline A8 & 5 & 5 & 5 & 2 & 5 & 5 & 2 & 2 & 5 & 5 \\
\hline Optimum & + & + & + & + & + & + & + & + & + & + \\
\hline
\end{tabular}

Faktor Pendukung Penjualan pada DOC Ayam Broiler (Agnes G. F. Simanjuntak)| 278 
Pada bagian ini diberikan hasil penelitian yang dilakukan sekaligus dibahas secara komprehensip. Hasil bisa berupa gambar, grafik, tabel dan lain-lain yang mempermudah pembaca paham dan diacu di naskah. Jika bahasan terlalu panjang dapat dibuat sub-sub judul, seperti contoh berikut.

\subsection{Proses Perhitungan Algoritma MO0RA}

Dari hasil rating kecocokan maka dapat dihasilkan matriks $\mathrm{x}$ :

$$
\mathbf{X}=\left[\begin{array}{l}
5552313442 \\
4433554443 \\
5123524511 \\
3344545355 \\
3344534434 \\
4345355443 \\
44554435554 \\
5552552255
\end{array}\right]
$$

Kemudian dilakukan normalisasi matriks terhadap masing-masing kriteria :

Kriteria 1 (C1)
$\begin{aligned} & \mathrm{X}=\sqrt{5^{2}+4^{2}+5^{2}+3^{2}+3^{2}+4^{2}+4^{2}+5^{2}} \\ & \begin{array}{ll}=11.874342087038 \\ \mathbf{C}_{1.1} \quad & =5 / 11.874342087038 \\ & =0.42107596053326\end{array} \\ & \begin{aligned} \mathbf{C}_{2.1} & =4 / 11.874342087038 \\ & =0.33686076842661\end{aligned} \\ & \mathbf{C}_{3.1}=5 / 11.874342087038 \\ & \quad=0.42107596053326 \\ & \mathbf{C}_{4.1} \quad=3 / 11.874342087038\end{aligned}$

$$
\begin{aligned}
& =0.25264557631996 \\
\mathbf{C}_{5.1} & =3 / 11.874342087038 \\
& =0.25264557631996 \\
\mathbf{C}_{6.1} & =4 / 11.874342087038 \\
& =0.33686076842661 \\
\mathbf{C}_{7.1} & =4 / 11.874342087038 \\
& =0.33686076842661 \\
\mathbf{C}_{8.1} & =5 / 11.874342087038 \\
& =0.42107596053326
\end{aligned}
$$

\section{Kriteria 2 (C2)}

$X=\sqrt{5^{2}+4^{2}+1^{2}+3^{2}+3^{2}+3^{2}+4^{2}+5^{2}}$

$=10.488088481702$

$$
\begin{aligned}
\mathbf{C}_{1.2} & =5 / 10.488088481702 \\
& =0.4767312946228 \\
\mathbf{C}_{2.2} & =4 / 10.488088481702 \\
& =0.38138503569824 \\
\mathbf{C}_{3.2} & =1 / 10.488088481702 \\
& =0.095346258924559 \\
\mathbf{C}_{4.2} & =3 / 10.488088481702
\end{aligned}
$$

\section{Kriteria 3 (C3)}

$X=\sqrt{5^{2}+3^{2}+2^{2}+4^{2}+4^{2}+4^{2}+5^{2}+5^{2}}$

$=11.661903789691$
$\mathbf{C}_{1.3}=5 / 11.661903789691$
$=0.42874646285627$
$\mathbf{C}_{2.3}=3 / 11.661903789691$

$$
\begin{aligned}
& =0.28603877677368 \\
\mathbf{C}_{5.2} & =3 / 10.488088481702 \\
& =0.28603877677368 \\
\mathbf{C}_{6.2} & =3 / 10.488088481702 \\
& =0.28603877677368 \\
\mathbf{C}_{7.2} & =4 / 10.488088481702 \\
& =0.38138503569824 \\
\mathbf{C}_{8.2} & =5 / 10.488088481702 \\
& =0.4767312946228
\end{aligned}
$$

$$
\begin{aligned}
& =0.25724787771376 \\
\mathbf{C}_{3.3} & =2 / 11.661903789691 \\
& =0.17149858514251 \\
\mathbf{C}_{4.3} & =4 / 11.661903789691 \\
& =0.34299717028502 \\
\mathbf{C}_{5.3} & =4 / 11.661903789691
\end{aligned}
$$




$$
\begin{aligned}
& =0.34299717028502 \\
\mathbf{C}_{6.3} & =4 / 11.661903789691 \\
& =0.34299717028502 \\
\mathbf{C}_{7.3} & =5 / 11.661903789691
\end{aligned}
$$

\section{Kriteria 4 (C4)}

$X=\sqrt{2^{2}+3^{2}+3^{2}+4^{2}+4^{2}+5^{2}+4^{2}+2^{2}}$ $=9.9498743710662$

$$
\begin{aligned}
\mathbf{C}_{1.4} & =2 / 9.9498743710662 \\
& =0.20100756305184 \\
\mathbf{C}_{2.4} & =3 / 9.9498743710662 \\
& =0.30151134457776 \\
\mathbf{C}_{3.4} & =3 / 9.9498743710662 \\
& =0.30151134457776 \\
\mathbf{C}_{4.4} & =4 / 9.9498743710662
\end{aligned}
$$

\section{Kriteria (C5)}

$\mathrm{X}=\sqrt{3^{2}+5^{2}+5^{2}+5^{2}+5^{2}+3^{2}+4^{2}+5^{2}}$

$=12.609520212918$
$\mathbf{C}_{1.5}=3 / 12.609520212918$
$=0.23791547571544$
$\mathbf{C}_{2.5}=5 / 12.609520212918$
$=0.39652579285907$
$\mathbf{C}_{3.5}=5 / 12.609520212918$
$=0.39652579285907$
$\mathbf{C}_{4.5}=5 / 12.609520212918$

\section{Kriteria 6 (C6)}

$X=\sqrt{1^{2}+5^{2}+2^{2}+4^{2}+3^{2}+5^{2}+3^{2}+5^{2}}$
$\begin{array}{ll}=10.677078252031 \\ \mathbf{C}_{1.6} & =1 / 10.677078252031 \\ & =0.093658581158169 \\ \mathbf{C}_{2.6} & =5 / 10.677078252031 \\ & =0.46829290579085 \\ \mathbf{C}_{3.6} & =2 / 10.677078252031 \\ & =0.18731716231634 \\ \mathbf{C}_{4.6} & =4 / 10.677078252031\end{array}$

\section{Kriteria 7 (C7)}

$X=\sqrt{3^{2}+4^{2}+4^{2}+5^{2}+4^{2}+5^{2}+5^{2}+2^{2}}$

$=11.661903789691$

$\begin{aligned} \mathbf{C}_{1.7} & =3 / 11.661903789691 \\ & =0.25724787771376 \\ \mathbf{C}_{2.7} & =4 / 11.661903789691 \\ & =0.34299717028502 \\ \mathbf{C}_{5.7} & =4 / 11.661903789691\end{aligned}$

$$
\begin{aligned}
& =0.42874646285627 \\
\mathbf{C}_{8.3} & =5 / 11.661903789691 \\
& =0.42874646285627
\end{aligned}
$$

$$
\begin{aligned}
& =0.40201512610368 \\
\mathbf{C}_{5.4} & =4 / 9.9498743710662 \\
& =0.40201512610368 \\
\mathbf{C}_{6.4} & =5 / 9.9498743710662 \\
& =0.50251890762961 \\
\mathbf{C}_{7.4} & =4 / 9.9498743710662 \\
& =0.40201512610368 \\
\mathbf{C}_{8.4} & =2 / 9.9498743710662 \\
& =0.20100756305184
\end{aligned}
$$

$$
\begin{aligned}
& =0.39652579285907 \\
\mathbf{C}_{5.5} & =5 / 12.609520212918 \\
& =0.39652579285907 \\
\mathbf{C}_{6.5} & =3 / 12.609520212918 \\
& =0.23791547571544 \\
\mathbf{C}_{7.5} & =4 / 12.609520212918 \\
& =0.31722063428726 \\
\mathbf{C}_{8.5} & =5 / 12.609520212918 \\
& =0.39652579285907
\end{aligned}
$$

$$
\begin{aligned}
& =0.37463432463268 \\
\mathbf{C}_{5.6} & =3 / 10.677078252031 \\
& =0.28097574347451 \\
\mathbf{C}_{6.6} & =5 / 10.677078252031 \\
& =0.46829290579085 \\
\mathbf{C}_{7.6} & =3 / 10.677078252031 \\
& =0.28097574347451 \\
\mathbf{C}_{8.6} & =5 / 10.677078252031 \\
& =0.46829290579085
\end{aligned}
$$

$$
\begin{aligned}
& =0.34299717028502 \\
\mathbf{C}_{6.7} & =5 / 11.661903789691 \\
& =0.42874646285627 \\
\mathbf{C}_{3.7} & =4 / 11.661903789691 \\
& =0.34299717028502 \\
\mathbf{C}_{4.7} & =5 / 11.661903789691 \\
& =0.42874646285627 \\
\mathbf{C}_{7.7} & =5 / 11.661903789691
\end{aligned}
$$




$$
\begin{aligned}
& =0.42874646285627 \\
C_{8.7} & =2 / 11.661903789691
\end{aligned}
$$

$=0.17149858514251$

$$
\begin{aligned}
& =0.26620695282483 \\
\mathbf{C}_{5.8} & =4 / 11.269427669585 \\
& =0.35494260376645 \\
\mathbf{C}_{6.8} & =4 / 11.269427669585 \\
& =0.35494260376645 \\
\mathbf{C}_{7.8} & =5 / 11.269427669585 \\
& =0.44367825470806 \\
\mathbf{C}_{8.8} & =2 / 11.269427669585 \\
& =0.17747130188322
\end{aligned}
$$

\begin{tabular}{|c|c|}
\hline $\begin{array}{l}X=\sqrt{ } \\
=10\end{array}$ & $\begin{array}{l}2+3^{2}+1^{2}+5^{2}+4^{2}+3^{2}+4^{2}+5^{2} \\
24695076596\end{array}$ \\
\hline $\mathrm{C}_{1.10}$ & $\begin{array}{l}=2 / 10.24695076596 \\
=0.19518001458971\end{array}$ \\
\hline $\mathrm{C}_{2.10}$ & $\begin{array}{l}=3 / 10.24695076596 \\
=0.29277002188456\end{array}$ \\
\hline $\mathrm{C}_{3.10}$ & $\begin{array}{l}=1 / 10.24695076596 \\
=0.097590007294853\end{array}$ \\
\hline $\mathrm{C}_{4.10}$ & $=5 / 10.24695076596$ \\
\hline
\end{tabular}

$\mathbf{C}_{4.8}=3 / 11.269427669585$

\section{Kriteria 9 (C9)}

$X=\sqrt{4^{2}+4^{2}+1^{2}+5^{2}+3^{2}+4^{2}+5^{2}+5^{2}}$

$=11.532562594671$

$$
\begin{aligned}
\mathbf{C}_{1.9} & =4 / 11.532562594671 \\
& =0.34684398780965 \\
\mathbf{C}_{2.9} & =4 / 11.532562594671 \\
& =0.34684398780965 \\
\mathbf{C}_{3.9} & =1 / 11.532562594671 \\
& =0.086710996952412 \\
\mathbf{C}_{4.9} & =5 / 11.532562594671
\end{aligned}
$$

$$
\begin{aligned}
& =0.43355498476206 \\
\mathbf{C}_{5.9} & =3 / 11.532562594671 \\
& =0.26013299085724 \\
\mathbf{C}_{6.9} & =4 / 11.532562594671 \\
& =0.34684398780965 \\
\mathbf{C}_{7.9} & =5 / 11.532562594671 \\
& =0.43355498476206 \\
\mathbf{C}_{8.9} & =5 / 11.532562594671 \\
& =0.43355498476206
\end{aligned}
$$

\section{Kriteria 10 (C10)}

Berdasarkan perhitungan diatas selanjutnya mengoptimalisasikan nilai atribut dengan cara mengkalikannya dengan nilai bobot yang sudah ditentukan pada masing-masing kriteria yaitu sebagai berikut

Kriteria 1 (C1)
0,42107596053326
$* 0,10=$
$* 0,10=0,03368607684266$
0,33686076842661
0,42107596053326
0,25264557631996
$* 0,10=0,04210759605333$
$* 0,10=0,02526455763200$
* $0,10=0,02526455763200$ 


$\begin{array}{ll}0,33686076842661 & * 0,10=0,03368607684266 \\ 0,33686076842661 & * 0,10=0,03368607684266 \\ 0,42107596053326 & * 0,10=0,04210759605333\end{array}$

\section{Kriteria 2 (C2)}

0,47673129462280

* $0,10=0,04767312946228$

0,38138503569824

$* 0,10=0,03813850356982$

0,09534625892456

$* 0,10=0,00953462589246$

0,28603877677368

$* 0,10=0,02860387767737$

0,28603877677368

$* 0,10=0,02860387767737$

0,28603877677368

$* 0,10=0,02860387767737$

0,38138503569824

$* 0,10=0,03813850356982$

0,47673129462280

$* 0,10=0,04767312946228$

\section{Kriteria 3 (C3)}

0,42874646285627 0,25724787771376

0,17149858514251

0,34299717028502

$$
\begin{aligned}
& * 0,10=0,04287464628563 \\
& * 0,10=0,02572478777138 \\
& * 0,10=0,01714985851425 \\
& * 0,10=0,03429971702850 \\
& * 0,10=0,03429971702850 \\
& * 0,10=0,03429971702850 \\
& * 0,10=0,04287464628563 \\
& * 0,10=0,04287464628563
\end{aligned}
$$

0,34299717028502

0,34299717028502

0,42874646285627

0,42874646285627

\section{Kriteria 4 (C4)}

0,20100756305184

$* 0,10=0,02010075630518$

0,30151134457776

$* 0,10=0,03015113445778$

0,30151134457776

$* 0,10=0,03015113445778$

0,40201512610369

$* 0,10=0,04020151261037$

0,40201512610369

* $0,10=0,04020151261037$

0,50251890762961

$* 0,10=0,05025189076296$

0,40201512610369

$* 0,10=0,04020151261037$

0,20100756305184

* $0,10=0,02010075630518$

\section{Kriteria 5 (A5)}

$\begin{array}{ll}0,23791547571544 & * 0,10=0,02379154757154 \\ 0,39652579285907 & * 0,10=0,03965257928591 \\ 0,39652579285907 & * 0,10=0,03965257928591 \\ 0,39652579285907 & * 0,10=0,03965257928591 \\ 0,39652579285907 & * 0,10=0,03965257928591 \\ 0,23791547571544 * 0,10=0,02379154757154 \\ 0,31722063428726 * 0,10=0,03172206342873 \\ 0,39652579285907 * 0,10=0,03965257928591\end{array}$




\section{Kriteria 6 (C6)}

0,09365858115817

0,46829290579085

0,18731716231634

0,37463432463268

0,28097574347451

0,46829290579085

0,28097574347451

0,46829290579085

\section{Kriteria 7 (C7)}

0,25724787771376

0,34299717028502

0,34299717028502

0,42874646285627

0,34299717028502

0,42874646285627

0,42874646285627

0,17149858514251

\section{Kriteria 8 (C8)}

0,35494260376645

0,35494260376645

0,44367825470806

0,26620695282483

0,35494260376645

0,35494260376645

0,44367825470806

0,17747130188322

* 0,10

$=0,02572478777138$

$* 0,10=0,03429971702850$

$* 0,10=0,03429971702850$

$* 0,10=0,04287464628563$

$* 0,10=0,03429971702850$

$* 0,10=0,04287464628563$

$* 0,10=0,04287464628563$

$* 0,10=0,01714985851425$

$* 0,10=0,03549426037664$

$* 0,10=0,03549426037664$

$* 0,10=0,04436782547081$

$* 0,10=0,02662069528248$

$* 0,10=0,03549426037664$

$* 0,10=0,03549426037664$

$* 0,10=0,04436782547081$

$* 0,10=0,01774713018832$

\section{Kriteria 9 (C9)}

0,34684398780965

0,34684398780965

0,08671099695241

0,43355498476206

0,26013299085724

0,34684398780965

0,43355498476206

0,43355498476206

$$
\begin{aligned}
& * 0,10=0,03468439878096 \\
& * 0,10=0,03468439878096 \\
& * 0,10=0,00867109969524 \\
& * 0,10=0,04335549847621 \\
& * 0,10=0,02601329908572 \\
& * 0,10=0,03468439878096 \\
& * 0,10=0,04335549847621 \\
& * 0,10=0,04335549847621
\end{aligned}
$$

\section{Kriteria 10 (C10)}

0,19518001458971

0,29277002188456

0,09759000729485 


$\begin{array}{ll}0,48795003647427 & * 0,10=0,04879500364743 \\ 0,39036002917941 & * 0,10=0,03903600291794 \\ 0,29277002188456 & * 0,10=0,02927700218846 \\ 0,39036002917941 & * 0,10=0,03903600291794 \\ 0,48795003647427 & * 0,10=0,04879500364743\end{array}$

Kemudian setelah melakukan perkalian, maka berikutnya adalah menghitung nilai Yi dengan cara menjumlahkan setiap kriteria sesuai dengan kolom masingmasing alternatif karena nilai bobot setiap kriteria semuanya bernilai cost, yaitu sebagai berikut :

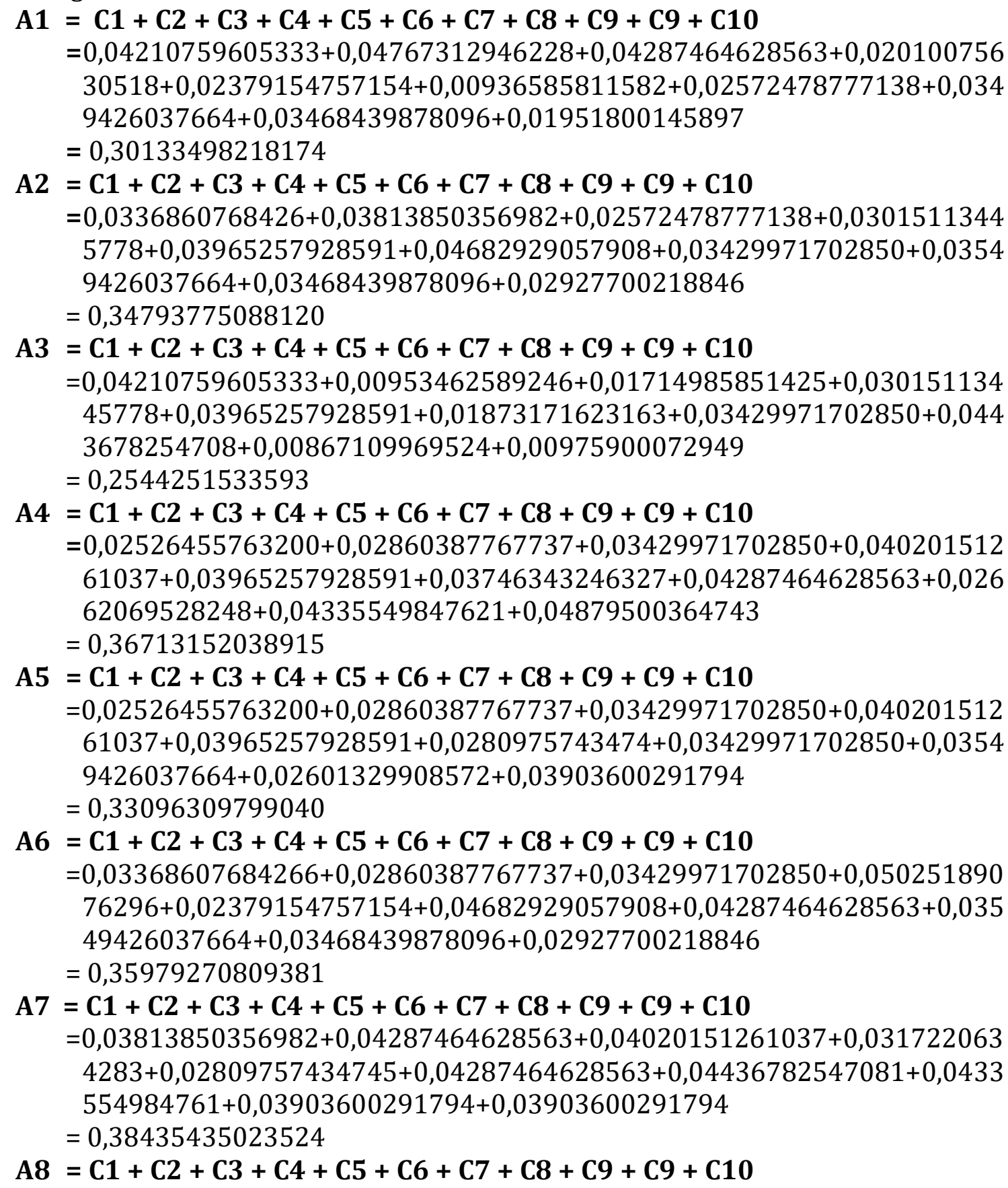




$$
\begin{aligned}
= & 0,04210759605333+0,04767312946228+0,04287464628563+0,020100756 \\
& 30518+0,03965257928591+0,04682929057908+0,01714985851425+0,017 \\
& 74713018832+0,04335549847621+0,04879500364743 \\
= & 0,36628548879762
\end{aligned}
$$

Setelah dilakukan perhitungan maka diperoleh hasil nilai Yi seperti pada Tabel berikut :

Tabel 13. Hasil Yi

\begin{tabular}{|c|c|c|}
\hline \multicolumn{2}{|c|}{ Alternatif } & Nilai \\
\hline Harga & A1 & 0,30133498218174 \\
\hline Pakan & A2 & 0,34793775088120 \\
\hline DOC Ayam & A3 & 0,25442515335938 \\
\hline Obat / Vaksin & A4 & 0,36713152038915 \\
\hline Pemanas & A5 & 0,33096309799040 \\
\hline Kandang & A6 & 0,35979270809381 \\
\hline Vitamin & A7 & 0,38435435023524 \\
\hline Anak Kandang & A8 & 0,36628548879762 \\
\hline
\end{tabular}

\section{KESIMPULAN}

Setelah melakukan penelitian lapangan, analisis data, perancangan, dan perhitungan komputerisasi yang telah dilakukan, maka diperoleh kesimpulan sebagai berikut:

a. Dari penelitian ini, dapat diketahui bahwa faktor vitamin yang memiliki nilai tertinggi menjadi faktor pendukung untuk meningkatkan penjualan pada DOC Ayam Broiler.

b. Dengan algoritma MOORA, analisa faktor pendukung penjualan pada DOC Ayam Broiler dapat diketahui sehingga bermanfaat dalam meningkatkan penjualan sesuai dengan hasil akhir perhitungan MOORA.

c. Dari hasil perhitungan dengan menggunakan metode MOORA dalam menentukan faktor pendukung pada DOC Ayam Broiler maka alternatif yang tertinggi sesuai dari urutan tertinggi sampai terendah yaitu alternatif A7 yaitu Vitamin dengan nilai 0,38435435023524, A4 yaitu Obat/Vaksin dengan nilai 0,36713152038915, A8 yaitu Anak Kandang dengan nilai 0,36628548879762, A6 yaitu Kandang dengan nilai 0,35979270809381, A2 yaitu Pakan dengan nilai 0,34793775088120, A5 yaitu Pemanas dengan nilai 0,33096309799040, dan alternatif terendah A1 yaitu Harga dengan nilai 0,30133498218174, A3 yaitu DOC Ayam dengan nilai 0,25442515335938. Maka dengan itu, dapat disimpulkan bahwa algoritma MOORA daat diterapkan pada aplikasi berbasis web dimana dari hasil perhitungan tersebut didapat kesamaan nilai antara sistem dan perhitungan menggunakan algoritma MOORA. Dari hasil tersebut dapat menjadi rekomendasi kepada PT. Karya Semangat Mandiri dalam menentukan faktor pendukung penjualan pada DOC Ayam Broiler.

\section{DAFTAR PUSTAKA}

[1] E. Sofia, "Kajian Aspek Ekonomis Penggunaan Heat Pump Sebagai Pemanas Alternatif Pada Kandang Peternakan Ayam Broiler Sistem Tertutup," Seminar Nasional Sains dan Teknologi Fakultas Teknik Universitas Muhammadiyah Jakarta, no. November, pp. 1-5, 2015.

[2] T. Imandasari, A. Wanto, and A. P. Windarto, "Analisis Pengambilan Keputusan Dalam 
Menentukan Mahasiswa PKL Menggunakan Metode PROMETHEE," Jurnal Riset Komputer (JURIKOM), vol. 5, no. 3, pp. 234-239, 2018.

[3] A. Wanto and E. Kurniawan, "Seleksi Penerimaan Asisten Laboratorium Menggunakan Algoritma AHP Pada AMIK-STIKOM Tunas Bangsa Pematangsiantar," Jurnal Informatika dan Komputer (JIKO), vol. 3, no. 1, pp. 11-18, 2018.

[4] A. Wanto and H. Damanik, "Analisis Penerapan Sistem Pendukung Keputusan Terhadap Seleksi Penerima Beasiswa BBM (Bantuan Belajar Mahasiswa) Pada Perguruan Tinggi Menggunakan Metode Simple Additive Weighting (SAW) (Studi Kasus : AMIK Tunas Bangsa Pematangsiantar)," in Seminar Nasional Rekayasa (SNTR) II, 2015, no. 2, pp. 323-333.

[5] M. Widyasuti, A. Wanto, D. Hartama, and E. Purwanto, "Rekomendasi Penjualan Aksesoris Handphone Menggunakan Metode Analitycal Hierarchy Process (AHP)," Konferensi Nasional Teknologi Informasi dan Komputer, vol. 1, no. 1, pp. 27-32, 2017.

[6] S. Sundari, A. Wanto, Saifullah, and I. Gunawan, "Sistem Pendukung Keputusan Dengan Menggunakan Metode Electre Dalam Merekomendasikan Dosen Berprestasi Bidang Ilmu Komputer (Study Kasus di AMIK \& STIKOM Tunas Bangsa)," in Seminar Nasional Multi Disiplin Ilmu, 2017, pp. 1-6.

[7] R. A. Hutasoit, S. Solikhun, and A. Wanto, "Analisa Pemilihan Barista dengan Menggunakan Metode TOPSIS (Studi Kasus: Mo Coffee)," KOMIK (Konferensi Nasional Teknologi Informasi dan Komputer), vol. 2, no. 1, pp. 256-262, 2018.

[8] N. Rofiqo, A. P. Windarto, and A. Wanto, "Penerapan Metode VIKOR Pada Faktor Penyebab Rendahnya Minat Mahasiswa Dalam Menulis Artikel Ilmiah," Seminar Nasional Sains \& Teknologi Informasi (SENSASI), vol. 1, no. 1, pp. 228-237, 2018.

[9] L. P. Purba, A. P. Windarto, and A. Wanto, "Faktor Terbesar Rendahnya Minat Ber-KB (Keluarga Berencana) dengan Metode ELECTRE II," Seminar Nasional Sains \& Teknologi Informasi (SENSASI), vol. 1, no. 1, pp. 369-374, 2018.

[10] M. Masitha, D. Hartama, and A. Wanto, "Analisa Metode (AHP) pada Pembelian Sepatu Sekolah Berdasarkan Konsumen," Seminar Nasional Sains \& Teknologi Informasi (SENSASI), vol. 1, no. 1, pp. 338-342, 2018.

[11] S. R. Ningsih, D. Hartama, A. Wanto, I. Parlina, and Solikhun, "Penerapan Sistem Pendukung Keputusan Pada Pemilihan Objek Wisata di Simalungun," in Seminar Nasional Teknologi Komputer \& Sains (SAINTEKS), 2019, pp. 731-735.

[12] S. Sundari, S. M. Sinaga, I. S. Damanik, and A. Wanto, "Sistem Pendukung Keputusan Pemilihan Peserta Olimpiade Matematika SMA Swasta Teladan Pematangsiantar Dengan Metode Electre," in Seminar Nasional Teknologi Komputer \& Sains (SAINTEKS), 2019, pp. 793-799.

[13] A. R. Hasibuan, S. W. Siregar, and N. Lubis, "Sistem Pendukung Keputusan Penenetuan Pemberian Bantuan Program Keluarga Harapan ( PKH ) Menerapkan Metode MOORA," pp. 386-390, 2018.

[14] S. W. Pasaribu, E. Rajagukguk, M. Sitanggang, R. Rahim, and L. A. Abdillah, "Implementasi Multi-Objective Optimization On The Basis Of Ratio Analysis ( MOORA) Untuk Menentukan Kualitas Buah Mangga Terbaik," Jurnal Riset Komputer (Jurikom), vol. 5, no. 1, pp. 50-55, 2018.

[15] S. N. Sains, N. I. Sarumaha, M. Simanungkalit, M. Damanik, and P. T. Informatika, "Sistem Pendukung Keputusan Penerimaan Pegawai Baru Menerapkan Metode VIKOR dan MOORA," pp. 193-214, 2018.

[16] H. Pratikno, "Pengaruh Ekstrak Kunyit ( Curcuma Domestica Vahl) Terhadap Bobot Badan Ayam Broiler ( Gallus Sp )," Buletin Anatomi dan Fisiologi, vol. 18, no. 2, pp. 39-46, 2010. 